\title{
Fibroblast growth factor 2 orchestrates angiogenic networking in non-GIST STS patients
}

\author{
Thomas K Kilvaer ${ }^{1 *}$, Andrej Valkov ${ }^{1,2}$, Sveinung W Sorbye ${ }^{1,2}$, Eivind Smeland ${ }^{4}$, Roy M Bremnes ${ }^{3,4}$, \\ Lill-Tove Busund ${ }^{1,2}$ and Tom Donnem ${ }^{3,4}$
}

\begin{abstract}
Background: Non-gastrointestinal stromal tumor soft-tissue sarcomas (non-GIST STSs) constitute a heterogeneous group of tumors with poor prognosis. Fibroblast growth factor 2 (FGF2) and fibroblast growth factor receptor-1 (FGFR-1), in close interplay with platelet-derived growth factor-B (PDGF-B) and vascular endothelial growth factor receptor-3 (VEGFR-3), are strongly involved in angiogenesis. This study investigates the prognostic impact of FGF2 and FGFR-1 and explores the impact of their co-expression with PDGF-B and VEGFR-3 in widely resected tumors from non-GIST STS patients.

Methods: Tumor samples from 108 non-GIST STS patients were obtained and tissue microarrays were constructed for each specimen. Immunohistochemistry was used to evaluate the expressions of FGF-2, FGFR-1, PDGF-B and VEGFR-3.

Results: In the multivariate analysis, high expression of FGF2 ( $\mathrm{P}=0.024, \mathrm{HR}=2.2,95 \% \mathrm{Cl} 1.1-4.4)$ and the co-expressions of FGF2 \& PDGF-B (overall; $P=0.007$, intermediate; $P=0.013, \mathrm{HR}=3.6,95 \% \mathrm{Cl}=1.3-9.7$, high; $\mathrm{P}=0.002, \mathrm{HR}=6.0,95 \% \mathrm{Cl}=2.0-18.1$ ) and FGF2 \& VEGFR-3 (overall; $\mathrm{P}=0.050$, intermediate; $\mathrm{P}=0.058, \mathrm{HR}=2.0$, $95 \% \mathrm{Cl}=0.98-4.1$, high; $\mathrm{P}=0.028, \mathrm{HR}=2.6,95 \% \mathrm{Cl}=1.1-6.0$ ) were significant independent prognostic indicators of poor disease-specific survival.
\end{abstract}

Conclusion: FGF2, alone or in co-expression with PDGF-B and VEGFR-3, is a significant independent negative prognosticator in widely resected non-GIST STS patients.

\section{Introduction}

Soft-tissue sarcomas (STSs) constitute a group of tumors of mesenchymal lineage, comprising over 50 histological entities [1]. The incidence is low and the lethality is high. With an estimate of 10000 new cases and nearly 4000 related deaths in the US in 2010, STSs remain one of the most aggressive types of cancer [2].

Current STS treatment comprises wide resection of the primary tumor with supplementary radiotherapy to those with high-grade lesions [3-5]. Since the use of chemotherapy is a challenge in adult STS, due to controversial efficacy [6], good prognostic and predictive indicators are highly warranted to help select patients for different types of chemotherapy treatments.

\footnotetext{
* Correspondence: Kilvaer@gmail.com

'Institute of Medical Biology, University of Tromso, PB 9037, Tromso, Norway
} Full list of author information is available at the end of the article
Fibroblast growth factors (FGFs) are heparin binding growth factors and as of today there are 18 FGFs and 4 fibroblast growth factor receptors (FGFRs) identified in humans [7]. The most extensive research in this field has been done on FGF2 (also known as basic fibroblast growth factor; bFGF), a growth factor primarily binding FGFR-1 [7]. FGF2 is a known promoter of angiogenesis and lymphangiogenesis [8]. Further, FGF2 stimulates cell growth and migration, but also, in some cases, differentiation [8].

Compared to healthy controls, plasma FGF2 levels, in sarcoma patients, is reported to be elevated. In contrast, low plasma FGF2 levels prior to surgery have been associated with an increased risk of recurrence [9-12]. FGF2 presence has also been confirmed in studies of sarcoma cell-lines [13].

FGF2 has been implicated as a player in different angiogenic and lymphangiogenic pathways [8]. Nissen et al. reported a reciprocal relationship between FGF2 and 
platelet-derived growth factor-B (PDGF-B) through their corresponding receptors [14]. Kubo et al. found FGF2 induced lymphangiogenesis to be blocked by vascular endothelial growth factor receptor-3 (VEGFR-3) inhibitors [15]. Further, in a study on human umbilical cord endothelial cells grown in the presence of VEGF-A, Welti et al. found FGF2 to rescue angiogenesis in presence of the VEGFR inhibitor Sunitinib ${ }^{\circledR}$ [16].

We have previously reported on the prognostic impact of the PDGFs and VEGFs and their receptors in this cohort of non-GIST STS patients $[17,18]$. The aim of this study was to investigate the prognostic impact of FGF2 and FGFR-1 expression, and their co-expressions with PDGF-B and VEGFR-3, in widely resected nonGIST STS patients.

\section{Patients and methods}

Patients and Clinical Samples

Primary tumor tissue from anonymized patients diagnosed with non-GIST STS at the University Hospital of North-Norway and the Hospitals of Arkhangelsk county, Russia, from 1973 through 2006, were collected. In total 496 patients were registered from the hospital databases. Of these, 388 patients were excluded from the study because of: missing clinical data $(n=86)$, inadequate paraffin-embedded fixed tissue blocks $(n=161)$ or nonwide resection margins $(n=141)$. Thus 108 patients with complete medical records, adequate paraffinembedded tissue blocks and wide resection margins were eligible.

This report includes follow-up data as of September 2009. The median follow-up was 68.4 (range 0.5-391.7) months. Complete demographic and clinical data were collected retrospectively. Formalin-fixed and paraffinembedded tumor specimens were obtained from the archives of the Departments of Pathology at the University Hospital of North-Norway and the Hospitals of Arkhangelsk County, Russia. The tumors were graded according to the French Fédération Nationale des centres de Lutte Contre le Cancer (FNCLCC) system and histologically subtyped according to the World Health Organization guidelines $[1,19]$. Wide resection margins were defined as wide local resection with free microscopic margins or amputation of the affected limb or organ.

\section{Microarray construction}

All sarcomas were histologically reviewed by two trained pathologists (S. Sorbye and A. Valkov) and the most representative areas of tumor cells (neoplastic mesenchymal cells) were carefully selected and marked on the hematoxylin and eosin $(\mathrm{H} / \mathrm{E})$ slide and sampled for the tissue microarray (TMA) blocks. The TMAs were assembled using a tissue-arraying instrument (Beecher
Instruments, Silver Springs, MD). The Detailed methodology has been previously reported [20,21]. Briefly, we used a $0.6 \mathrm{~mm}$ diameter stylet, and the study specimens were routinely sampled with four replicate core samples from different areas of neoplastic tissue. Normal tissue from the patients was used as staining control.

To include all core samples, 12 TMA blocks were constructed. Multiple $5-\mu \mathrm{m}$ sections were cut with a Micron microtome (HM355S) and stained by specific antibodies for immunohistochemistry (IHC) analysis.

\section{Immunohistochemistry}

The applied antibodies were subjected to in-house validation by the manufacturer for IHC analysis on paraffin-embedded material. The antibodies used in the study were FGF2 (rabbit polyclonal; AB1458; Chemicon; 1:200) and FGFR-1 (rabbit polyclonal; sc-121; Santa Cruz; 1:50). The IHC procedures for PDGF-B and VEGFR-3 have been previously described $[17,18]$.

Sections were deparaffinized with xylene and rehydrated with ethanol. Antigen retrieval was performed by placing the specimen in $0.01 \mathrm{M}$ citrate buffer at $\mathrm{pH} 6.0$ and exposed to microwave heating of 10 minutes at 250 W (FGF2) or heated by pressure boiler of 2 minutes (FGFR-1). The DAKO EnVision + System-HRP (DAB) kit was used as endogen peroxidase blocking. As negative staining controls, the primary antibodies were replaced with the primary antibody diluent. Primary antibodies were incubated for 30 minutes (FGF2) or 60 minutes (FGFR-1) in room temperature. The kit DAKO EnVision + System-HRP (DAB) was used to visualize the antigens. This was followed by application of liquid diaminobenzidine and substrate-chromogen, yielding a brown reaction product at the site of the target antigen. Finally, all slides were counter-stained with hematoxylin to visualize the nuclei. For each antibody, included negative staining controls, all TMA staining were performed in a single experiment.

\section{Scoring of immunohistochemistry}

The ARIOL imaging system (Genetix, San Jose, CA) was used to scan the slides of antibody staining of the TMAs. The slides were loaded in the automated slide loader (Applied Imaging SL 50) and the specimens were scanned at low resolution $(1.25 \times)$ and high resolution (20x) using the Olympus BX 61 microscope with an automated platform (Prior). Representative and viable tissue sections were scored manually on the computer screen semi-quantitatively for cytoplasmic staining. The dominant staining intensity was scored as: $0=$ negative; 1 = weak; 2 = intermediate; 3 = strong. All samples were anonymized and independently scored by two trained pathologists (A. Valkov and S. Sorbye). When assessing a variable for a given core, the observers were 
blinded to the scores of the other variables and to outcome. Mean score for duplicate cores from each individual was calculated separately.

High expression in tumor cells was defined as score $\geq$ 2 (FGF2 and FGFR-1) (Figure 1). The previously published cut-off values for PDGF-B and VEGFR-3 $(\geq 1.5)$ were used to estimate the co-expressions with FGF2 and FGFR-1 [17,18].

\section{Statistical Methods}

All statistical analyses were done using the statistical package SPSS (Chicago, IL), version 16. The IHC scores from each observer were compared for interobserver reliability by use of a two-way random effect model with absolute agreement definition. The intraclass correlation coefficient (reliability coefficient) was obtained from these results. The Chi-square test and Fishers Exact test were used to examine the association between molecular marker expression and various clinicopathological parameters. Univariate analyses were done using the Kaplan-Meier method, and statistical significance between survival curves was assessed by the log-rank test. Disease-specific survival (DSS) was determined from the date of diagnosis to the time of cancer related death. To assess the independent value of different

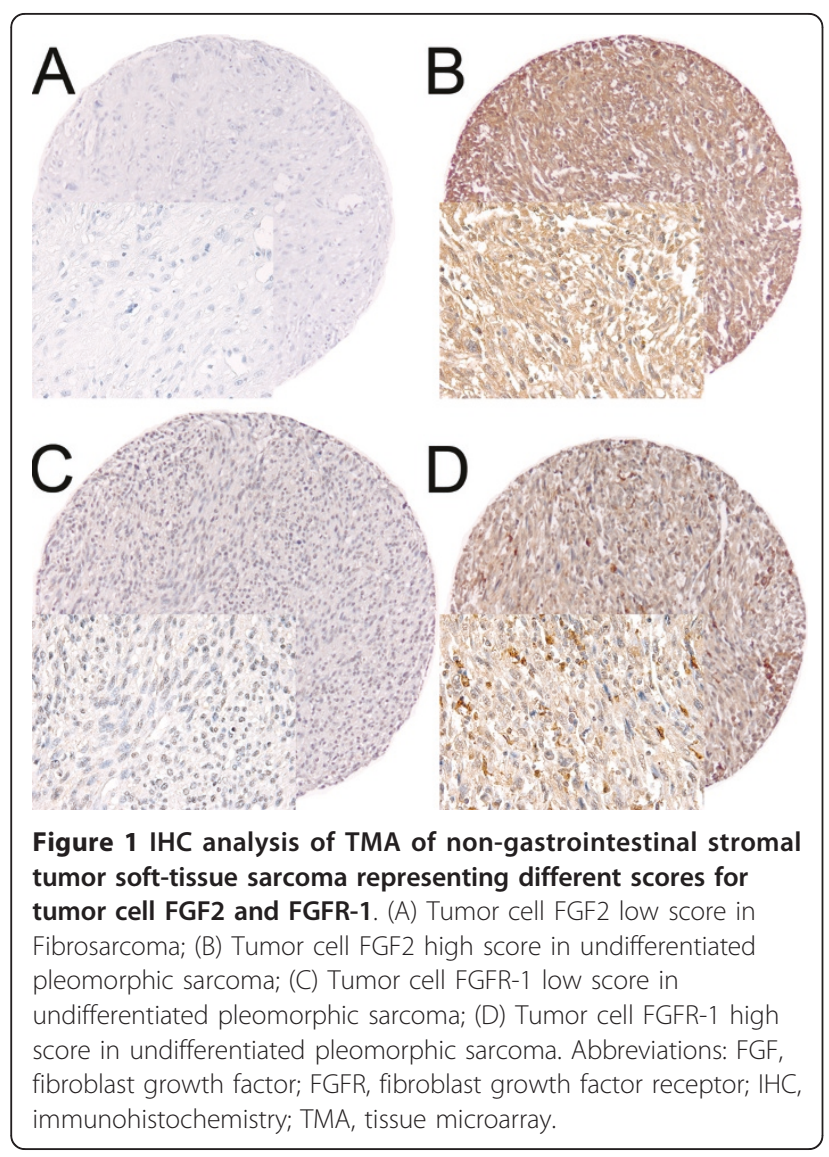

pretreatment variables on survival, in the presence of other variables, multivariate analyses were carried out using the Cox proportional hazards model. Only variables of significant value from the univariate analyses were entered into the Cox regression analysis. Probability for stepwise entry and removal was set at .05 and .10 , respectively. The significance level used for all statistical tests was $\mathrm{P}<0.05$.

\section{Ethical clearance}

The National Data Inspection Board and The Regional Committee for Research Ethics approved the study.

\section{Results}

\section{Clinopathological Variables}

The clinopathological variables are summarized in Table 1 . The median age was 57 (range $0-86$ ) years, $56 \%$ were female, 73 patients were Norwegian and 35 Russian. The Non-GIST STSs comprised 108 tumors including angiosarcoma $(n=5)$, fibrosarcoma $(n=8)$, leiomyosarcoma $(n=34)$, liposarcoma $(n=13)$, pleomorphic sarcoma $(n=29)$, neurofibrosarcoma/malignant peripheral nerve sheath tumor (MPNST, $\mathrm{n}=5$ ), rhabdomyosarcoma $(n=6)$, synovial sarcoma $(n=6)$ and unspecified sarcoma $(n=2)$. The tumor origins were distributed as follows: $43 \%$ extremities, $19 \%$ trunk, $7 \%$ retroperitoneal, $4 \%$ head/neck and $28 \%$ visceral. In addition to surgical resection, 6 patients received both radio-and chemotherapy, 23 patients received chemotherapy alone and 15 patients received radiotherapy alone.

\section{Interobserver variability}

Interobserver scoring agreement was tested for FGF2 and FGFR-1. The intraclass correlation coefficients were 0.80 for FGF2 $(\mathrm{P}<0.001)$ and 0.93 for FGFR-1 $(\mathrm{P}<$ 0.001 ), indicating good reproducibility between the investigating pathologists.

\section{Expression of FGF2/FGFR-1 and their Correlations}

FGF2/FGFR-1 expression was localized in the cytoplasm of tumor cells.

FGF2 did not correlate with the clinical variables while low FGFR-1 expression correlated with small tumor size (low expression; < $50 \mathrm{~mm} \mathrm{44 \% ,} \mathrm{50-100} \mathrm{mm} \mathrm{34 \% ,} \mathrm{>} 100$ $\mathrm{mm} 22 \%, \mathrm{P}=0.005)$.

\section{Univariate Analyses}

Table 1 summarizes the prognostic impact of the clinopathological variables. Patient nationality $(\mathrm{P}<0.001)$, malignancy grade $(\mathrm{P}<0.001)$, tumor depth $(\mathrm{P}=0.009)$ and metastasis at diagnosis $(\mathrm{P}<0.001)$ were prognostic indicators of DSS.

The influence on DSS by FGF2 and FGFR-1 are given in Table 2 and Figure 2 panels $A$ and B. High 
Table 1 Prognostic clinicopathological variables as predictors for disease-specific survival in patients with completely resected non-gastrointestinal stromal tumor soft-tissue sarcomas (univariate analyses, log rank test; multivariate analysis, Cox regression analysis)

\begin{tabular}{|c|c|c|c|c|c|c|c|c|}
\hline \multirow[b]{2}{*}{ Characteristics } & \multicolumn{5}{|c|}{ Univariate analyses } & \multicolumn{3}{|c|}{ Multivariate analysis } \\
\hline & $\begin{array}{l}\text { Patients } \\
\text { (n) }\end{array}$ & $\begin{array}{l}\text { Patients } \\
\text { (\%) }\end{array}$ & $\begin{array}{c}\text { Median } \\
\text { survival } \\
\text { (months) }\end{array}$ & $\begin{array}{c}\text { 5-Year } \\
\text { survival } \\
(\%)\end{array}$ & $\mathbf{P}$ & $\mathrm{HR}$ & $95 \% \mathrm{Cl}$ & $P$ \\
\hline \multicolumn{9}{|l|}{ Age } \\
\hline$\leq 20$ years & 7 & 7 & $N R$ & 57 & 0.960 & & & \\
\hline $21-60$ years & 55 & 51 & NR & 64 & & & & \\
\hline$>60$ years & 46 & 43 & NR & 60 & & & & \\
\hline \multicolumn{9}{|l|}{ Gender } \\
\hline Male & 47 & 44 & NR & 74 & 0.054 & & & \\
\hline Female & 61 & 56 & 127 & 53 & & & & \\
\hline \multicolumn{9}{|l|}{ Patient nationality } \\
\hline Norwegian & 73 & 68 & $N R$ & 73 & $<0.001$ & 1.000 & & \\
\hline Russian & 35 & 32 & 22 & 38 & & 2.777 & $1.457-5.292$ & 0.002 \\
\hline \multicolumn{9}{|l|}{ Histological entity } \\
\hline Pleomorphic sarcoma & 29 & 27 & 54 & 50 & 0.127 & & & \\
\hline Leiomyosarcoma & 34 & 32 & 68 & 53 & & & & \\
\hline Liposarcoma & 13 & 12 & $N R$ & 92 & & & & \\
\hline Fibrosarcoma & 8 & 7 & NR & 88 & & & & \\
\hline Angiosarcoma & 5 & 5 & NR & 60 & & & & \\
\hline Rhabdomyosarcoma & 6 & 6 & NR & 67 & & & & \\
\hline MPNST & 5 & 5 & NR & 80 & & & & \\
\hline Synovial sarcoma & 6 & 6 & 59 & 80 & & & & \\
\hline Sarcoma NOS & 2 & 2 & NR & 100 & & & & \\
\hline \multicolumn{9}{|l|}{ Tumor localization } \\
\hline Extremities & 46 & 43 & NR & 66 & 0.735 & & & \\
\hline Trunk & 21 & 19 & $N R$ & 60 & & & & \\
\hline Retroperitoneum & 7 & 7 & NR & 71 & & & & \\
\hline Head/Neck & 4 & 4 & NR & 75 & & & & \\
\hline Visceral & 30 & 28 & 63 & 53 & & & & \\
\hline \multicolumn{9}{|l|}{ Tumor size } \\
\hline$\leq 5 \mathrm{~cm}$ & 40 & 37 & $N R$ & 75 & 0.262 & & & \\
\hline $5-10 \mathrm{~cm}$ & 46 & 43 & NR & 53 & & & & \\
\hline$>10 \mathrm{~cm}$ & 20 & 18 & NR & 60 & & & & \\
\hline Missing & 2 & 2 & & & & & & \\
\hline Malignancy grade & & & & & & & & $0.015^{*}$ \\
\hline 1 & 32 & 30 & NR & 90 & $<0.001$ & 1.000 & & \\
\hline 2 & 36 & 33 & NR & 61 & & 3.808 & $1.084-13.380$ & 0.037 \\
\hline 3 & 40 & 37 & 32 & 39 & & 5.937 & $1.721-20.481$ & 0.005 \\
\hline \multicolumn{9}{|l|}{ Tumor depth } \\
\hline Superficial & 12 & 11 & $* *$ & $* *$ & 0.009 & $* *$ & $* *$ & $* *$ \\
\hline Deep & 96 & 89 & & 57 & & & & \\
\hline \multicolumn{9}{|l|}{ Metastasis at diagnosis } \\
\hline No & 97 & 90 & 218 & 66 & $<0.001$ & 1.000 & & \\
\hline Yes & 11 & 10 & 8 & 27 & & 4.689 & $2.004-10.972$ & $<0.001$ \\
\hline \multicolumn{9}{|l|}{ Chemotherapy } \\
\hline No & 79 & 73 & NR & 65 & 0.234 & & & \\
\hline Yes & 29 & 27 & 120 & 55 & & & & \\
\hline \multicolumn{9}{|l|}{ Radiotherapy } \\
\hline No & 87 & 81 & $N R$ & 63 & 0.375 & & & \\
\hline Yes & 21 & 19 & NR & 57 & & & & \\
\hline
\end{tabular}

Abbreviations: NR, not reached; MPNST, malignant peripheral nerve sheath tumor; NOS, not otherwise specified; *, overall significance as a prognostic factor; **all cases were censored. 
Table 2 Tumor expression of FGF2, FGFR-1 and the co-expressions of FGF2 \& PDGF-B and FGF2 \& VEGFR-3 and their prediction for disease-specific survival in patients with completely resected non-gastrointestinal stromal tumor softtissue sarcomas (univariate analyses, log rank test; multivariate analysis, Cox regression analysis)

\begin{tabular}{|c|c|c|c|c|c|c|c|c|}
\hline \multicolumn{4}{|c|}{ Univariate analyses } & \multicolumn{5}{|c|}{ Multivariate analysis } \\
\hline Marker expression & $\begin{array}{l}\text { Patients } \\
\text { (n) }\end{array}$ & $\begin{array}{l}\text { Patients } \\
\text { (\%) }\end{array}$ & $\begin{array}{l}\text { Median } \\
\text { survival } \\
\text { (months) }\end{array}$ & $\begin{array}{c}\text { 5-Year } \\
\text { survival } \\
(\%)\end{array}$ & $\mathbf{P}$ & $\mathrm{HR}$ & $95 \% \mathrm{Cl}$ & $\mathbf{P}$ \\
\hline \multicolumn{9}{|l|}{ FGF2 } \\
\hline Low & 75 & 69 & NR & 68 & 0.048 & 1.000 & & \\
\hline High & 30 & 28 & 54 & 50 & & 2.203 & $1.108-4.379$ & 0.024 \\
\hline Missing & 3 & 3 & & & & & & \\
\hline \multicolumn{9}{|l|}{ FGFR-1 } \\
\hline Low & 78 & 72 & NR & 61 & 0.830 & & & \\
\hline High & 28 & 26 & NR & 62 & & & & \\
\hline Missing & 2 & 2 & & & & & & \\
\hline FGF2 \& PDGF-B & & & & & & & & $0.007^{*}$ \\
\hline Low & 27 & 25 & NR & 81 & 0.011 & 1.000 & & \\
\hline Intermediate & 52 & 48 & NR & 59 & & 3.569 & $1.311-9.715$ & 0.013 \\
\hline High & 25 & 23 & 45 & 48 & & 5.971 & $1.966-18.132$ & 0.002 \\
\hline Missing & 4 & 4 & & & & & & \\
\hline FGF2 \& VEGFR-3 & & & & & & & & $0.050^{*}$ \\
\hline Low & 51 & 47 & NR & 70 & 0.042 & 1.000 & & \\
\hline Intermediate & 35 & 32 & 120 & 56 & & 1.999 & $0.978-4.087$ & 0.058 \\
\hline High & 16 & 15 & 45 & 46 & & 2.584 & $1.106-6.038$ & 0.028 \\
\hline Missing & 6 & 6 & & & & & & \\
\hline \multicolumn{9}{|l|}{ FGFR-1 \& PDGF-B } \\
\hline Low & 26 & 24 & NR & 75 & 0.061 & & & \\
\hline Intermediate & 56 & 52 & 120 & 55 & & & & \\
\hline High & 23 & 21 & NR & 58 & & & & \\
\hline Missing & 3 & 3 & & & & & & \\
\hline \multicolumn{9}{|l|}{ FGFR-1 \& VEGFR-3 } \\
\hline Low & 57 & 53 & NR & 66 & 0.344 & & & \\
\hline Intermediate & 29 & 27 & 120 & 59 & & & & \\
\hline High & 18 & 17 & 63 & 52 & & & & \\
\hline Missing & 4 & 4 & & & & & & \\
\hline
\end{tabular}

Abbreviations: FGF, fibroblast growth factor; FGFR, fibroblast growth factor receptor; NR, not reached; PDGF, platelet-derived growth factor; VEGFR, vascular endothelial growth factor receptor; * overall significance as prognostic factor.

expression of FGF 2 was significantly $(\mathrm{P}=0.048)$ associated with a poor prognosis.

\section{Multivariate Cox Proportional Hazards Analysis}

Table 1 and 2 summarizes the results of the multivariate analysis of clinopathological variables and marker expression, respectively. Russian nationality $(\mathrm{P}=0.002)$, high malignancy grade $(\mathrm{P}=0.015)$, metastasis at diagnosis $(\mathrm{P}<0.001)$ and high FGF2 expression $(\mathrm{P}=0.024$, $\mathrm{HR}=2.203$, 95\% CI 1.11-4.38) were significant independent negative indicators of DSS.

\section{Co-expressions}

In univariate analyses, the co-expressions of FGF2 \& PDGF-B $(\mathrm{P}=0.011)$ and FGF2 \& VEGFR-3 $(\mathrm{P}=0.042)$ were significant prognostic indicators of DSS (Table 2).
In the multivariate analyses, high expression of FGF2 \& PDGF-B was, when compared to low expression, a significant independent prognostic indicator of poor DSS $(\mathrm{HR}=6.0,95 \% \mathrm{CI}=1.966-18.132, \mathrm{P}=0.002)$. High expression of FGF2 \& VEGFR-3 $(\mathrm{HR}=2.6,95 \% \mathrm{CI}=$ 1.106-6.038, $\mathrm{P}=0.028$ ) was also a significant independent prognosticator (Table 2, Figure 2 panels $C$ and D). Figure 3 shows proposed actions of expressed FGF2, PDGF-B and VEGFRs in non-GIST STSs.

\section{Discussion}

In the study presented herein we have observed high tumor expression of FGF2 and the co-expressions of FGF2 \& PDGF-B and FGF2 \& VEGFR-3 to be significant, independent and unfavorable prognostic indicators of DSS in non-GIST STS patients with wide resection 


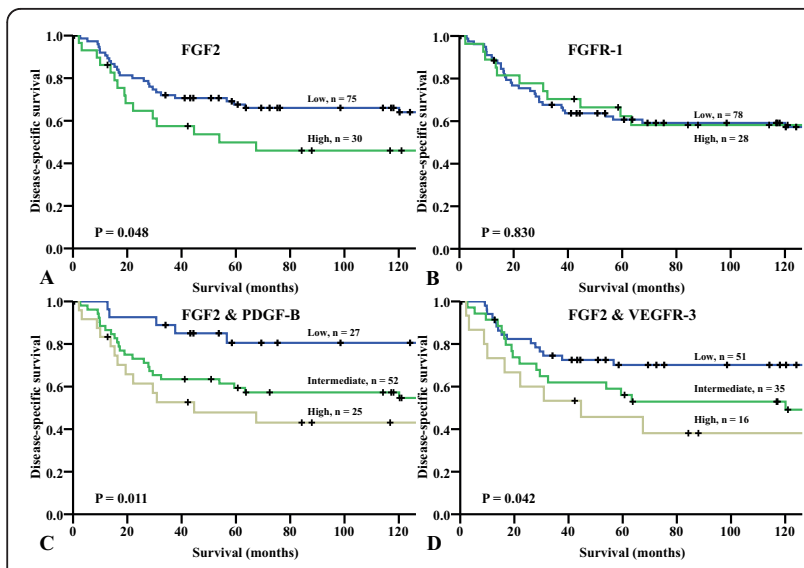

Figure 2 Disease-specific survival curves for (A) FGF2; (B) FGFR1; (C) FGF2 \& PDGF-B; (D) FGF2 \& VEGFR-3. Abbreviations: FGF, fibroblast growth factor; FGFR, fibroblast growth factor receptor; PDGF, platelet-derived growth factor; VEGFR, vascular endothelial growth factor receptor

margins. Few studies have investigated FGF2 and FGFR1 in STS and no previous studies have reported on the co-expressions with PDGF-B and VEGFR-3. To our knowledge this is the first evaluation of these pathways in non-GIST STSs.

We have previously reported on the prognostic impact of PDGFs and VEGFs in this patient cohort $[17,18]$. In the previous investigations we found the prognostic impact of these growth factors and their pathways to be dependent on wide resection margins. Without wide resection margins, the prognosis is poor with only $30 \%$ 5 -year survivors and angiogenic markers could not distinguish between prognostic groups.

Our results are, by large, consistent with previously published data on FGF2 in STSs. Graeven et al. reported that FGF2 levels in serum of STS patients were elevated in comparison to that of controls [12]. Yoon et al., using microarray techniques, found FGF2 gene-expression to be significantly higher in STS patient tissue samples compared to healthy controls [11]. We found high FGF2 expression in tumor to be a significant independent negative prognostic marker in non-GIST STS patients with wide resection margins.

There are several ways in which FGF2 can promote non-GIST STS development, as illustrated in Figure 3. Endothelial cells treated with FGF2 in vitro and in vivo form tubes, proliferate and are induced to migrate [8]. Further, FGF2 has also been associated with extracellular matrix remodeling, pivotal in angiogenesis/lymphangiogenesis, through increased release and expression of matrix metallo-proteinases and urokinase-like plasminogen activator [8]. In addition, FGF2 has recently been shown to rescue PDGF-B transfected cells undergoing Imatinib ${ }^{\circledR}$ induced apoptosis [22] and to sustain the

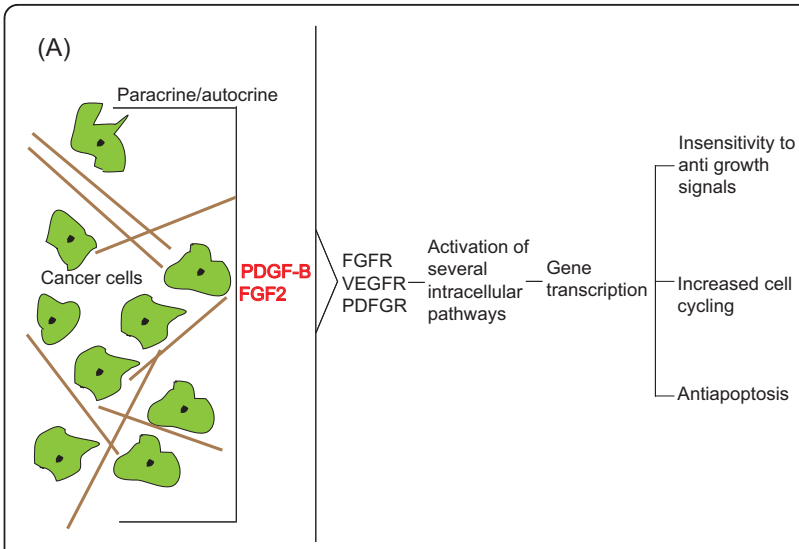

(B)

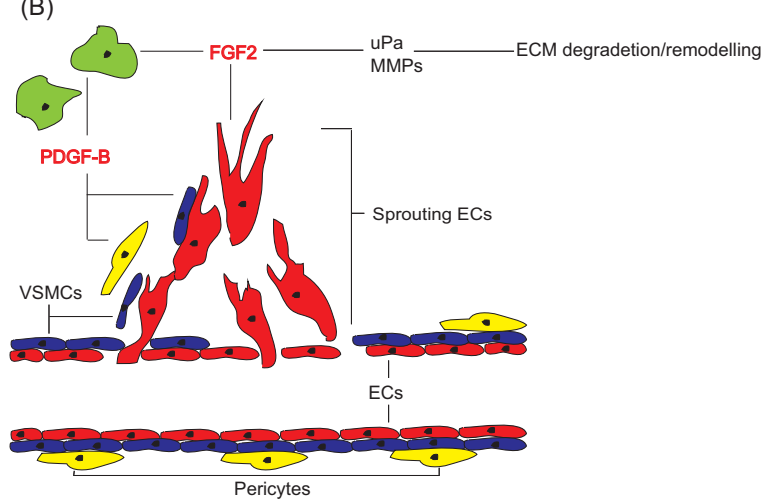

Figure 3 Proposed mechanisms of stimulation of growth, angiogenesis and motility in non-gastrointestinal stroma tumor soft-tissue sarcomas expressing FGF2, PDGF-B and VEGFR-3. (A) Paracrin and/or autocrin stimulation of cancer cells leading to activation of intracellular pathways and subsequently survival benefits; (B) FGF2 stimulating angiogenesis through recruitment of endothelial cells and increasing release of MMPs and uPa leading to ECM degradation and remodeling thus enabling tumor cell expansion and motility, PDGF-B recruiting VSMCs and stimulating pericyte coverage of newly formed vessle; Abbreviations: ECM, extracellular matrix; FGF, fibroblast growth factor; FGFR, fibroblast growth factor receptor; PDGF, platelet-derived growth factor; PDGFR, platelet-derived growth factor receptor; MMP, matrixmetallo proteinase; UPa, urokinase-like plasminogen activator; VEGF, vascular endothelial growth factor; VEGFR, vascular endothelial growth factor receptor.

angiogenic profile of human umbilical cord cells grown with VEGF-A in the presence of the VEGFR inhibitor Sunitinib ${ }^{\circledR}$ [16]. Angiogenesis is one of the hallmarks of cancer and adaptation of an angiogenic profile is one of the deciding steps in carcinogenesis [23]. These latter results indicate that the FGF pathway contributes to the redundancy observed when targeting angiogenesis in cancer (Figure $3 b$ ). In addition, FGF2 could function as a growth factor on the tumor cells in a paracrine/autocrine fashion, activating intracellular pathways and ultimately leading cells to proliferate, avoid apoptosis or become insensitive to antigrowth signals (Figure 3a) $[8,24]$. 
PDGF-B is an important stabilizer of blood-vessels, working as a chemotactic and proliferative agent on vascular smooth muscle cells (VSMCs) and pericytes [25-27]. Nissen et al. investigated the possibility of interactions between the FGF2 and PDGF-B signaling pathways and found FGF2 and PDGF-B to synergistically induce neovascularization in murine fibrosarcomas [14]. In our cohort, patients who expressed high intensity staining of PDGF-B and FGF2 had HR's of 3.9 or 2.2 [18], respectively, in comparison to those expressing low intensity staining. Examining the co-expression of FGF2 \& PDGF-B revealed a HR of 6.0 for the high-high expression group (Table 2), indicating an additive or possibly a synergetic effect of these pathways in nonGIST STSs.

VEGFR-3 is classically associated with lymphangiogenesis, but has recently been linked to angiogenesis $[28,29]$. Using the mouse corneal assay, Kubo et al. found FGF2 induced angiogenesis to be blocked by administration of VEGFR-3 inhibitors, indicating an interaction between these pathways [15]. Previously, we found non-GIST STS patients with wide resection margins expressing high intensity VEGFR-3 staining to have a HR of 2.0 compared to those with low intensity staining [17]. For the co-expression of FGF2 \& VEGFR-3 we found a HR of 2.6 in the high-high expression group, indicating a modest additive effect between these pathways in non-GIST STSs.

FGF2, PDGF-B and VEGFR-3 expression leads to activation of several different intracellular pathways including PI3K, MEKK, SEK, PLC $\gamma$ and others. Further studies to investigate the relative involvement of these pathways in sarcoma angiogenesis development would be of great interest. Players in these pathways could prove to be targets for novel therapeutic approaches both together with cytokine binding antibodies and receptor blockers and alone.

We have previously found FGF2 and the co-expressions of FGF2 \& PDGF-B and FGF2 \& VEGFR-3 to be poor independent prognosticators in an unselected large non-small cell lung cancer cohort [30]. The finding of similar results in cancers derived from different embryonic cell-layers may indicate that tumor vasculogenesis as a whole, or at least for certain mechanisms, are universal processes.

\section{Conclusion}

The angiogenic and lymphangiogenic systems have redundant and synergetic properties making it difficult to target these pathways with chemotherapy alone. Nevertheless, we observed that high expression of FGF2 and the co-expressions of FGF2 \& PDGF-B and FGF2 \& VEGFR-3 are significant independent negative prognostic factors in widely resected non-GIST STS patients.
These results suggest that the angiogenic properties of sarcomas are versatile and complex, hence multitargeted antiangiogenic treatment could prove an interesting approach in non-GIST STSs.

\section{Funding}

This study was funded by the Northern Norway Health Authority, The Norwegian Childhood Cancer Network, The Norwegian Sarcoma Group, The Norwegian Cancer Society and The University of Tromso.

\section{List of abbreviations}

bFGF: basic fibroblast growth factor; Cl: confidence interval; DSS: diseasespecific survival; FGF: fibroblast growth factor; FGFR: fibroblast growth factor receptor; FNCLCC: French Fédération Nationale des centres de Lutte Contre le Cancer; H/E: hematoxylin/eosin; HR: hazard rate; IHC:

immunohistochemistry; MMP: matrix metallo proteinase; MPNST: malignant peripheral nerve sheath tumor; Non-GIST STS: non-gastrointestinal stromal tumor soft tissue sarcoma; NOS: not otherwise specified; NR: not reached; PDGF: platelet-derived growth factor; PDGFR: platelet-derived growth factor receptor; STS: soft tissue sarcoma; VEGF: vascular endothelial growth factor; VEGFR: vascular endothelial growth factor receptor; TMA: tissue microarray; uPa: urokinase-like plasminogen activator.

\section{Aknowlegdements}

Thanks to Frode Skjold for coupling of databases, Magnus L. Persson for making the TMA blocks and Helge Stalsberg for helping to collect clinical information.

\section{Author details}

1 Institute of Medical Biology, University of Tromso, PB 9037, Tromso, Norway. 2 Department of Clinical Pathology, University Hospital of North Norway, PB 9038, Tromso, Norway. ${ }^{3}$ Institute of Clinical Medicine, University of Tromso, PB 9037, Tromso, Norway. ${ }^{4}$ Department of Oncology, University Hospital of North Norway, PB 9038, Tromso, Norway.

\section{Authors' contributions}

All authors participated in the study design, result interpretation and in the writing. TK, AV, SS and ES contributed in making the clinical and

demographic database. TK, SS and AV scored the cores. TK and TD did the statistical analysis. TK drafted the manuscript. All authors read and approved the final manuscript.

\section{Competing interests}

The authors declare that they have no competing interests.

Received: 23 February 2011 Accepted: 6 July 2011

Published: 6 July 2011

\section{References}

1. Fletcher CDM, Unni KK, Mertens F: Pathology and genetics of tumours of soft tissue and bone. Lyon: IARC Press; 2002.

2. Jemal A, Siegel R, Xu J, Ward E: Cancer statistics, 2010. CA Cancer J Clin 2010, 60(5):277-300

3. Dickinson IC, Whitwell DJ, Battistuta D, Thompson B, Strobel N, Duggal A, Steadman P: Surgical margin and its influence on survival in soft tissue sarcoma. ANZ J Surg 2006, 76(3):104-109.

4. Mendenhall WM, Indelicato DJ, Scarborough MT, Zlotecki RA, Gibbs CP, Mendenhall NP, Mendenhall CM, Enneking WF: The management of adult soft tissue sarcomas. Am J Clin Oncol 2009, 32(4):436-442.

5. Kaushal A, Citrin D: The role of radiation therapy in the management of sarcomas. Surg Clin North Am 2008, 88(3):629-646.

6. Thornton K: Chemotherapeutic management of soft tissue sarcoma. Surg Clin North Am 2008, 88(3):647-660.

7. Beenken A, Mohammadi M: The FGF family: biology, pathophysiology and therapy. Nat Rev Drug Discov 2009, 8(3):235-253. 
8. Presta M, Dell'Era P, Mitola S, Moroni E, Ronca R, Rusnati M: Fibroblast growth factor/fibroblast growth factor receptor system in angiogenesis. Cytokine Growth Factor Rev 2005, 16(2):159-178.

9. Ruka W, Rutkowski P, Kaminska J, Rysinska A, Steffen J: Alterations of routine blood tests in adult patients with soft tissue sarcomas: relationships to cytokine serum levels and prognostic significance. Ann Oncol 2001, 12(10):1423-1432.

10. Yoon SS, Segal NH, Olshen AB, Brennan MF, Singer S: Circulating angiogenic factor levels correlate with extent of disease and risk of recurrence in patients with soft tissue sarcoma. Ann Oncol 2004, 15(8):1261-1266

11. Yoon SS, Segal NH, Park PJ, Detwiller KY, Fernando NT, Ryeom SW, Brennan MF, Singer S: Angiogenic profile of soft tissue sarcomas based on analysis of circulating factors and microarray gene expression. J Surg Res 2006, 135(2):282-290

12. Graeven U, Andre N, Achilles E, Zornig C, Schmiegel W: Serum levels of vascular endothelial growth factor and basic fibroblast growth factor in patients with soft-tissue sarcoma. J Cancer Res Clin Oncol 1999, 125(10):577-581.

13. Hu M, Nicolson GL, Trent JC, Yu D, Zhang L, Lang A, Killary A, Ellis LM, Bucana CD, Pollock RE: Characterization of 11 human sarcoma cell strains: evaluation of cytogenetics, tumorigenicity, metastasis, and production of angiogenic factors. Cancer 2002, 95(7):1569-1576.

14. Nissen LJ, Cao R, Hedlund EM, Wang Z, Zhao X, Wetterskog D, Funa K, Brakenhielm E, Cao Y: Angiogenic factors FGF2 and PDGF-BB synergistically promote murine tumor neovascularization and metastasis. J Clin Invest 2007, 117(10):2766-2777.

15. Kubo H, Cao R, Brakenhielm E, Makinen T, Cao Y, Alitalo K: Blockade of vascular endothelial growth factor receptor-3 signaling inhibits fibroblast growth factor-2-induced lymphangiogenesis in mouse cornea. Proc Natl Acad Sci USA 2002, 99(13):8868-8873.

16. Welti JC, Gourlaouen M, Powles T, Kudahetti SC, Wilson P, Berney DM, Reynolds AR: Fibroblast growth factor 2 regulates endothelial cell sensitivity to sunitinib. Oncogene 2010

17. Kilvaer TK, Valkov A, Sorbye S, Smeland E, Bremnes RM, Busund LT, Donnem T: Profiling of VEGFs and VEGFRs as Prognostic Factors in Soft Tissue Sarcoma: VEGFR-3 Is an Independent Predictor of Poor Prognosis. PLoS One 2010, 5(12):e15368.

18. Kilvaer TK, Valkov A, Sorbye SW, Donnem T, Smeland E, Bremnes RM, Busund LT: Platelet-Derived Growth Factors in Non-GIST Soft-Tissue Sarcomas Identify a Subgroup of Patients with Wide Resection Margins and Poor Disease-Specific Survival. Sarcoma 2010, 2010(2010):10..

19. Guillou L, Coindre JM, Bonichon F, Nguyen BB, Terrier P, Collin F, Vilain MO, Mandard AM, Le Doussal V, Leroux A, Jacquemier J, Duplay H, SastreGarau X, Costa J: Comparative study of the National Cancer Institute and French Federation of Cancer Centers Sarcoma Group grading systems in a population of 410 adult patients with soft tissue sarcoma. J Clin Oncol 1997, 15(1):350-362.

20. Donnem T, Al-Saad S, Al-Shibli K, Delghandi MP, Persson M, Nilsen MN, Busund LT, Bremnes RM: Inverse prognostic impact of angiogenic marker expression in tumor cells versus stromal cells in non small cell lung cancer. Clin Cancer Res 2007, 13(22 Pt 1):6649-6657.

21. Bremnes RM, Veve R, Gabrielson E, Hirsch FR, Baron A, Bemis L, Gemmill RM, Drabkin HA, Franklin WA: High-throughput tissue microarray analysis used to evaluate biology and prognostic significance of the Ecadherin pathway in non-small-cell lung cancer. J Clin Oncol 2002, 20(10):2417-2428.

22. Ohshima M, Yamaguchi Y, Kappert K, Micke P, Otsuka K: bFGF rescues imatinib/STI571-induced apoptosis of sis-NIH3T3 fibroblasts. Biochem Biophys Res Commun 2009, 381(2):165-170.

23. Hanahan D, Weinberg RA: The hallmarks of cancer. Cell 2000, 100(1):57-70.

24. Dailey L, Ambrosetti D, Mansukhani A, Basilico C: Mechanisms underlying differential responses to FGF signaling. Cytokine Growth Factor Rev 2005, 16(2):233-247.

25. Lindblom P, Gerhardt H, Liebner S, Abramsson A, Enge M, Hellstrom M, Backstrom G, Fredriksson S, Landegren U, Nystrom HC, Bergstrom G, Dejana E, Ostman A, Lindahl P, Betsholtz C: Endothelial PDGF-B retention is required for proper investment of pericytes in the microvessel wall. Genes Dev 2003, 17(15):1835-1840.
26. Abramsson A, Lindblom P, Betsholtz C: Endothelial and nonendothelial sources of PDGF-B regulate pericyte recruitment and influence vascular pattern formation in tumors. J Clin Invest 2003, 112(8):1142-1151.

27. Betsholtz C: Insight into the physiological functions of PDGF through genetic studies in mice. Cytokine Growth Factor Rev 2004, 15(4):215-228.

28. Tammela T, Zarkada G, Wallgard E, Murtomaki A, Suchting S, Wirzenius M, Waltari M, Hellstrom M, Schomber T, Peltonen R, Freitas C, Duarte A, Isoniemi H, Laakkonen P, Christofori G, Yla-Herttuala S, Shibuya M, Pytowski B, Eichmann A, Betsholtz C, Alitalo K: Blocking VEGFR-3 suppresses angiogenic sprouting and vascular network formation. Nature 2008, 454(7204):656-660.

29. Tammela T, Enholm B, Alitalo K, Paavonen K: The biology of vascular endothelial growth factors. Cardiovasc Res 2005, 65(3):550-563.

30. Donnem T, Al-Shibli K, Al-Saad S, Busund LT, Bremnes RM: Prognostic impact of fibroblast growth factor 2 in non-small cell lung cancer: coexpression with VEGFR-3 and PDGF-B predicts poor survival. J Thorac Oncol 2009, 4(5):578-585.

doi:10.1186/1479-5876-9-104

Cite this article as: Kilvaer et al:: Fibroblast growth factor 2 orchestrates angiogenic networking in non-GIST STS patients. Journal of Translational Medicine 2011 9:104.

\section{Submit your next manuscript to BioMed Central and take full advantage of:}

- Convenient online submission

- Thorough peer review

- No space constraints or color figure charges

- Immediate publication on acceptance

- Inclusion in PubMed, CAS, Scopus and Google Scholar

- Research which is freely available for redistribution

Submit your manuscript at www.biomedcentral.com/submit
Ciomed Central 